\title{
Boards: Independent and Committed Directors?
}

\section{Christophe Volonté* \\ University of Basel}

The final publication is available at sciencedirect.com. DOI: 10.1016/j.irle.2014.10.002

[forthcoming in International Review of Law and Economics]

\begin{abstract}
Regulators, proxy advisors and shareholders are regularly calling for independent directors. However, at the same time, independent directors commonly engage in numerous outside activities potentially reducing their time and commitment with the particular firm. Using Tobin's Q as an approximation of market valuation and controlling for endogeneity, our empirical analysis reveals that neither is independence positively related to firm performance nor are outside activities negatively related to it. Nevertheless, we find that - nonindependent - executive directors, former executives and family representatives have a positive relationship with Tobin's Q. Conversely, - independent - outside executives are negatively related with firm valuation. Moreover, the study indicates that the frequency and duration of meetings are negatively affected by the fraction of executive directors on the board. Insiders potentially reduce the need for meetings because of their specialist competence. The results therefore invalidate rules advocating independent directors and oppose the engagement of directors with significant outside activities.
\end{abstract}

JEL-Classification: G30; G34; K22

Keywords: Corporate governance; Board of directors; Board independence; Outside activities

*Corresponding author. Christophe Volonté. christophe.volonte@unibas.ch; Tel: +41-61-267-24-62.

Dr. Christophe Volonté is a post-doc researcher at the Department of Financial Management, University of Basel, Faculty of Business and Economics, Peter Merian-Weg 6, CH-4002 Basel, Switzerland. E-mail: christophe.volonte@unibas.ch 


\section{Introduction}

Most economists agree that a board of directors' essential duty is to ensure that a firm is led in the shareholders' best interests. The board of directors is positioned between a firm's top management and its shareholders who typically have insufficient ownership to influence firm policies. Therefore, prescriptive legislation imposes serious responsibilities on directors and defines the public expectation of their performance. Two important responsibilities of the board of directors are the monitoring and advising of the top management. The first task, which is rooted in agency theory, stresses the importance of the director's role in solving the principal-agent conflict between managers and shareholders (see Jensen and Meckling 1976; Fama and Jensen 1983). In this context, the board's independence from management is crucial. The second task emphasizes the importance of the director's role providing ties with the external business environment and professional specialist skills (for example, strategic planning). This latter responsibility is associated with outside activities (for example, outside directorships, executive positions or political engagements) of directors and is based on resource dependence theory (Pfeffer and Salancik 1978). However, these two roles are subject to trade-offs.

The first trade-off relates to the position (or independence) of the board vis-à-vis the top management. Board directors need sufficient information about the daily business and risks of the firm to do a proper job. The information asymmetry between the management and the board of directors can be reduced by continuing communication of the two parties. Executive directors (insiders) can close this gap. However, insiders virtually supervise themselves and executive directors may be too involved in daily business, so that their view may conflict with an outside, more neutral, perspective. In addition, also a close relationship, friendship or even dependence on the chief executive officer (CEO) and his executive board can impair the board's independence and lead to collusion and conflicts of interest. For instance, compromised board decisions may involve executives being replaced too late or paid too much, counter to shareholder interests (Adams and Ferreira 2007). This is particularly difficult where the CEO has a lot of decision-making power as in the nomination of new directors (see Shivdasani and Yermack 1999).

As a consequence of these potential imbalances, regulators, proxy advisors and shareholders are regularly calling for independent directors. ${ }^{1}$ The literature traditionally

\footnotetext{
${ }^{1}$ See Sarbanes-Oxley Act (SOX) of 2002 Section 301(m)(3)(A): "In general — Each member of the audit committee of the issuer shall be a member of the board of directors of the issuer, and shall otherwise be independent." This direct and exogenous impact led to a reduction of insiders on U.S.
} 
classifies board members as insiders and outsiders (see Hermalin and Weisbach 2003; Yermack 2004). Executive directors are commonly defined as being insiders, while nonexecutive directors are denominated as being outsiders. Nevertheless, not all of these outsiders are independent. Such directors are often referred to as "grey" or "affiliated" directors. As a common rule, directors are considered independent if they are not currently employed by the firm or if a gap of three years has elapsed since previous employment there, and if they have neither financial nor business ties to the firm (see Swiss Code). ${ }^{2}$

The call for independent directors launched in the United States has led to the appointment of directors who have neither financial nor personal relations to the firm. In consequence, independent "professional" directors may engage in a significant number of other outside activities (for example, outside directorships, executive positions or political engagements), assuming that a directorship is generally not a full-time job.

Therefore, the second trade-off is characterized by time constraints imposed by competing allegiances and conflicts of interest imposed by competing activities, which, however, may provide benefits of business experience and external linkages. On the one hand, these outside engagements may reduce the time allocated to any single directorship. This, in turn, reduces their monitoring capacity and potentially exacerbates the agency problem, raising the agency costs that they were employed to reduce in the first place. On the other hand, experienced directors with multiple appointments provide important linkages to the external environment. In addition, with multiple directorships, directors are not uniquely financially dependent on one single seat for remuneration, thus allowing them more scope to voice their views independently in discussions in the board room (see von der Crone 2005). Such factors may facilitate business in uncertain economic environments. All the same, increasingly,

boards of unregulated firms from 2001 to 2004 (see Linck, Netter, and Yang 2008). Especially small firms with traditionally higher proportions of insiders lowered their share. By 2004, only few firms still had insider-dominated boards. Besides, board sizes increased due to a higher complexity and requirements of the board. As a matter of fact, the fraction of such independent directors has risen from 22 percent to 73 percent in the period from 1950 until 2005 in the United States (Gordon 2007). Accordingly, the fraction of inside directors or grey directors has decreased to 16 and 11 percent, respectively.

${ }^{2}$ In addition, non-independence can also apply to directors with relations to significant shareholders or directors with a long tenure (see “Code de Gouvernement d'Entreprise des Sociétés Cotées” in France or "Combined Code of Corporate Governance" in the United Kingdom). Firms may also employ additional independence criteria. For instance, the Swiss bank UBS employs 13 independence criteria based on the Corporate Governance Listing Standards of the New York Stock Exchange for board members and 16 for members of the audit committee (http://www.ubs.com/1/g/investors/corporategovernance/ independencecriteria.html, access on 21/02/2011). 
governance codes recommend restricting the number of external directorships, as is the case in the Netherlands or France. ${ }^{3}$

In light of regulations and shareholders calling for board independence and a limitation regarding the number of outside activities adopted, the question arises whether such rules improve the effectiveness of the board and as a result, the value of all firms on average. Directors must have the requisite capacity and skill to fulfill their function, and must devote the necessary time and effort to the discharge of their duties. From a judicial point of view, insufficient effort, skills or time do not release directors from their duty of care. This suggests that individuals with multiple board seats encounter serious danger of violating good faith. Hence, the examination of these questions has policy implications. A legislation amendment for all firms that, however, only improves the corporate governance of specific firms (for example large and international banks) may adversely affect and seriously burden all other firms since the optimality of board composition is affected by the firm's requirements (see e.g. Hermalin and Weisbach 2003). Inappropriate rules restrict the freedom of firms to organize their board structure according to their needs in a value-maximizing manner. In short, corporate governance reforms are only beneficial and welfare-improving if the neteffect over all firms is positive.

Therefore, a problem in modern boards lies in the trade-off between board independence and the outside activities of independent directors. Current research on the topic fails to explicitly connect independence with outside activities. Some do so implicitly by investigating the impact of so-called "busy" outsiders on firm performance (Ferris, Jagannathan, and Pritchard 2003; Fich and Shivdasani 2006). Furthermore, studies use broad proxies for either independence or outside activities. And finally, most academic papers focus on the U.S. market where ownership is dispersed, requirements for independent directors exigent, and a large pool of directors available.

We address the two issues (independence and outside activities) and examine their effect on firm performance in Switzerland. Swiss firms are an interesting research object for two reasons. Firstly, the legislature allows insiders to occupy positions on the board of directors, as is the case in market-oriented governance systems ("one-tier board structure"). Thus, a board can consist of executive directors (insiders), as well as non-executive directors (outsiders), and the leadership structure can also be combined (where the CEO is also

\footnotetext{
3 “Dutch Corporate Governance Code. Principles of Good Corporate Governance and Best Practice Provisions" by the Corporate Governance Code Monitoring Committee and "Recommendations on Corporate Governance" by the Association Française de la Gestion Financière.
} 
chairman). ${ }^{4}$ The Swiss one-tier board structure contrasts the two-tiered board system stipulated in Germany (and other continental European countries) which strictly separates the supervisory board ("Aufsichtsrat") from the management board ("Vorstand"). In a dualistic system, no variance in board composition relating to executive directors can be observed, and consequently, empirical investigations are not possible. In Switzerland such examinations are feasible.

Secondly, the narrow or illiquid market for directors generates low supply of directors (see Loderer and Peyer 2002). A special feature of Switzerland as a small economy is its high concentration of large global firms, which used to be controlled by a relatively small number of business leaders. The so-called "old boys network" operated through business associations, societies, interest groups, political affiliations, and the Swiss Army. Famous examples of business leaders include Fritz Gerber, Rainer E. Gut, and Ulrich Bremi. Later, a new group of connected directors appeared with the likes of Rolf Hüppi, Andres Leuenberger, and Lukas Mühlemann. Nowadays, important business leaders are less active in politics, although many politicians are members of politically influenced boards in the utilities and health industry sectors. Over the past two decades, the average board size decreased from 15 to 11 board members, precipitating a fall in the number of cross-relationships. ${ }^{5}$ Moreover, Swiss directors have been replaced by directors from abroad to some extent. While in 1988, 87 percent of all board members were Swiss males, this number gradually decreased to 35 percent in 2012 (Volonté 2014). Even though some directors are very active today, the network intensity cannot be compared to 20 years ago. Further statistical features underline this perception. In 2008, 1,574 director seats were shared with 1,349 directors. Hence, the ratio of seats to directors is 86 percent. In comparison, this ratio was 93 percent for SMI firms in 2012 (and 73 percent in 1988) (Volonté 2014).

Our study uses a host of refined variables to measure independence (10 variables) and outside activities (11 variables). The definitions go beyond the usual classification of independent or "busy" directors made by regulators and academic researchers. This way, we aim to explain the inconclusive results of past studies that may have been driven by deficits in variable specifications. Furthermore, this breakdown allows us also to examine which factors really drive board structure-performance relationships. We tackle endogeneity issues using a

\footnotetext{
${ }^{4} \mathrm{CEO}$ duality is given if one person holds both the job of the CEO and the chairman of the board of the same firm.

${ }^{5}$ In 2012, only four directors of our sample hold four or more board appointments in Swiss

Performance Index (SPI) firms. All of them are Swiss, male, and over 50 years old.
} 
battery of control variables, fixed effects models and two-stage least squares method. After all, our research findings document whether investors trust specific types of directors categorized by the extent to which they act in the shareholders' best interests.

\section{Literature Review}

Board of directors should be composed of directors with various functions and skills. Baysinger and Butler (1985) suggest that directors execute distinct functions on boards. They categorize directors' functions into three board categories: insiders carrying out executive functions, independent directors acting in a monitoring capacity, and other directors who are instrumentally engaged in providing, for instance, legal counsel. The board's composition should reflect the firm's needs in relation to the directors' functions also in relation to their independence and external commitments.

\subsection{Board Independence}

The effect of board composition (and independence) on firm performance or firm policy (namely CEO dismissal) is a topic researched in legal, business, and finance literature. Executive directors might face conflicts of interest because their job includes supervising themselves, among other things. Thereby, the proportion of insiders or the extent of CEO duality is expected to negatively impact firm performance. For this reason, shareholders, namely institutional investors, favor independent boards: TIAA-CREF, a large U.S. mutual fund, only invests in firms which have a majority of outside directors, and CalPERS, a large U.S. pension fund, suggests that the CEO should be the only insider on a board (see Bhagat and Black 1999; Coles, Daniel, and Naveen 2008). Furthermore, some U.S. stock exchanges such as the NYSE and NASDAQ also require a majority of outside directors; also SOX requires independent audit committees. The most obvious problem associated with board independence concerns the leadership structure of a firm. CEO duality is fervently debated. Dual mandates are widely argued to have a negative impact on firm performance. Accordingly, Bhagat and Bolton (2008) demonstrate in an empirical paper that a separation of the functions is beneficial for performance. In contrast, Brickley, Coles, and Jarrell (1997) find evidence that a separation is detrimental to performance, as it is value-decreasing. And both Baliga, Moyer, and Rao (1996) and Schmid and Zimmermann (2008) show that neither the stock price nor performance is affected by a change in the leadership structure. Faleye (2007) explains these results by arguing that the benefits of a separation depend on CEO and firm characteristics. 
From a more general perspective, research on board independence focuses on the composition of the board with outside or more strictly, independent directors. Independent directors are expected to be more likely to protect the shareholders' interests than insiders would. As evidence of this theory, Weisbach (1988) finds that CEOs of poorly performing firms are more frequently removed by outsider-dominated boards than by insider-dominated boards. However, several studies find no or a negative relationship between outsiders and firm performance (e.g., Hermalin and Weisbach 1991; Yermack 1996; Agrawal and Knoeber 1996; Klein 1998; Bhagat and Black 1999; Bhagat and Black 2002; Beiner et al. 2006; Bhagat and Bolton 2008).

In contrast, using various identification strategies, Black and Kim (2012) using regulatory changes, Nguyen and Nielsen (2010) using independent director's sudden death, and Knyazeva, Knyazeva and Masulis (2013) using local director pool find a positive effect of board independence on firm value.

Anderson and Reeb (2004) underline the perception that independent directors represent minority shareholders' interests. In balancing family and minority interests, independent directors add value to family firms and limit the family's opportunity to extract private benefits of control. However, independent directors may also have links to the firm and management that are not obvious in the first place. For instance, Cohen, Frazzini and Malloy (2012) find evidence that analysts who are technically independent are chosen to boards when their prior recommendation as analysts were in favor of the firm.

It is also important to remember that empirical results are prone to be influenced by sample firms (namely institutional environment of the country studied, industry affiliation, firm size, and ownership structure of the firms) and the period of the study (for example, before or after the introduction of SOX, see e.g., Helland and Sykuta 2004).

\subsection{Outside Activities of Directors}

The outside activities of directors comprise engagements directors hold outside the specific firm board. Expressed in terms of market economics, we expect a growth in directors' outside activities or engagements in case of a seller's market for directorships. Fama (1980) as well as Fama and Jensen (1983) argue that reliable — "good" — supervisors and managerial talent may be rewarded with directorships. However, directors with numerous external appointments may have insufficient time for their board duties owing to over-commitment. Fich and Shivdasani (2007) find supporting evidence for this view. They reveal that the number of additional directorships that a director has declines if the firm faces shareholder 
class action lawsuits following financial fraud. Cai, Garner, and Walkling (2009) show that shareholders punish lazy directors. Their results indicate that directors are normally elected by large majorities with voting rights in excess of 90 percent. In contrast, incumbent directors who attend fewer meetings receive fewer shareholder votes (-14 percent). Masulis and Mobbs (2014) show that directors devote more time to directorships with higher prestige and conclude that reputation plays an important role for independent directors. Similarly, de Jong, Hooghiemstra, and van Rinsum (2014) find that intrinsic motives affect a director's decision to join a board.

Most empirical studies on multiple directorships find that there is a negative relationship with firm performance. Fich and Shivdasani (2006) define "busy boards" as being composed of a majority of outside directors holding three or more directorships. Their results indicate that such boards are negatively related to profitability and market-to-book ratios; additionally, CEO turnover sensitivity to firm performance is lower. Also, Jiraporn et al. (2008) find that directors holding multiple board seats negatively affect firm value. In contrast, Ferris, Jagannathan, and Pritchard (2003) find no evidence that busy directors serve less responsibly and therefore reject policies limiting the number of outside directorships.

Many studies directly link the number of directorships to firm performance, suggesting, for instance, that time constraints translate into lower firm valuation. Nevertheless, one important question is how multiple directorships affect firm performance. Over-commitment of external board members' has also been shown to be related to valued-decreasing firm strategies (see e.g., Jiraporn et al. 2008; Ahn, Jiraporn, and Kim 2010). Yermack (2006) demonstrates that stock price effects due to major events in one firm are transmitted to other firms that share the same director.

Boards are often composed by external executives, especially CEOs, and politicallyconnected people. According to Lorsch and MacIver (1989), managers know best how to optimally monitor managers. However, some corporate governance codes recommend a maximum number of directorships for executives, and CEOs are less likely to serve on boards today than 10 years ago (see Spencer Stuart 2010). ${ }^{6}$ One notorious problem again is the constraint on time, because CEO positions are demanding and time-consuming. Conyon and Read (2006) argue that executives will accept a larger number of outside appointments than is optimal for their primary employer. Additionally, conflicts can also occur where directors

6 In Germany, corporate managers should not have more than three supervisory board seats from listed firms ("Deutscher Corporate Governance Kodex"). In France, executives should not have more than four outside directorships (“Code de Gouvernement d’Entreprise des Sociétés Cotées”). 
represent interests of both supply and demand. Nevertheless, Masulis and Mobbs (2011) prove that inside directors with outside directorships are positively related to market-to-book ratios and operating performance. In addition, event-studies show that the market reaction on the appointment of CEOs (Fich 2005) and executives appointed from firms with low agency problems (Perry and Peyer 2005) is positive. In contrast, Fahlenbrach, Low, and Stulz (2010) do not find any positive effect of CEOs appointed as outside directors on firm performance. Their results depict a negative effect if it is an interlocking CEO. Recurrent findings illustrate that regulated firms have more directors with a background in politics and that politicians on board have an impact on firm value (Agrawal and Knoeber 2001; Helland and Sykuta 2004; Hillman 2005 Goldman, Rocholl, and So (2009)).

In summary, while provisions for independent boards have been launched by investors and regulators, the empirical evidence supporting board-performance effects is mixed, whether it is concerned with CEO duality or the proportion of independent directors on the board (Schmid and Zimmermann 2008; Bhagat and Bolton 2008). With respect to directors' outside activities, our literature review shows that most studies find a negative relationship between the number of directorships and firm performance (Fich and Shivdasani 2006; Jiraporn et al. 2008). In contrast, the presence of politicians and inside directors with external directorships on boards seems to be value-enhancing (Hillman 2005; Masulis and Mobbs 2011). This supports the notion that the board can consist of various types of directors. The optimal composition of the board may not be equal for every firm, thus calling for a consideration of individual firm characteristics.

\section{Data Description and Definition of Variables}

The Directive on Information Relating to Corporate Governance from SIX Swiss Exchange requires all listed firms to disclose relevant information about their directors. This information includes a curriculum vitae, an outline of the director's position vis-à-vis the firm, and a list of their external professional activities. ${ }^{7}$ The detailed data provides the basis for this study.

\subsection{Data}

All firms of the Swiss Performance Index (SPI) with complete annual reports in 2008 excluding "investment firms" and "financial services" were targeted. Therefore, the selection

\footnotetext{
7 "Other activities and functions; For each member of the board of directors: (a) Activities in governing and supervisory bodies of important Swiss and foreign organizations, institutions and foundations under private and public law; (b) Permanent management and consultancy functions for important Swiss and foreign interest groups; (c) Official functions and political posts." (see SIX Directive on Information Relating to Corporate Governance 3.2).
} 
bias is negligible (except that non-listed firms are excluded). The sample thus consists of 1,494 firms whose annual reports enabled us to hand-collect data on 10,683 directors. Crosschecking the data of directors who hold directorships in two or more listed firms reveals that not all annual reports disclose the same information. The details disclosed on multiple directorships varied across firms. Some exceptions restrict the disclosure to only relevant pieces of information; for example, membership of other listed firms. In consequence, the data was aligned where possible.

\subsection{Firm Performance: Tobin's $Q$}

We use Tobin's $Q$ as a proxy for firm performance. Our Tobin's $Q$ is calculated as the total assets plus market value of equity minus book value of total equity divided by total assets (see Agrawal and Knoeber 1996; Loderer and Peyer 2002; Beiner et al. 2006). ${ }^{8}$ The omitted intangible assets in the book value reflect - among other things - the director competence or investor confidence in the board's composition.

\subsection{Independence Variables}

Independence variables describe the board's relation to the firm. As Adams, Hermalin, and Weisbach (2010) point out, outsiders are frequently not really independent, stressing the need to account for additional variables of board independence. Independence is the fraction of independent directors on the board. Independence defines directors who are neither actual Executives, nor Grey (or affiliated) directors. Affiliated directors have current Business relationships with the firm or were Former executives of the firm. Additional variables are used to classify the director's Full independence. Long tenure is the fraction of directors with tenure longer than nine years such as in the UK's Combined Code. Blockholding directors is the fraction of directors with significant shareholdings (more than three percent of voting rights). Finally, Shareholder representatives and Family representatives indicate the fraction of directors who represent a shareholder or a family, respectively, other than themselves.

\subsection{Outside Activity Variables}

Outside activity variables describe board-member engagements outside the firm. First, the aggregate of any board directors' outside activities (for example, other directorships or

\footnotetext{
${ }^{8}$ In this study, all classes of equity including non-listed equity classes are used for the calculation of the market value of equity. The market value of equity is the average stock price 15 days around the last trading day in 2007, multiplied by the number of outstanding shares.
} 
engagements in politics or charities) divided by the number of board members is labelled Outside activities. SPI directorships denotes all SPI directorships or SPI chairmanships. Second, chairmanships (Chairmanships) and directorships (Directorships) measure the total number of concurrent (Swiss or foreign) board seats someone holds as chairman or director, respectively. If annual reports refer to "various" or "other" directorships, we add a value of three. We do not include directorships in subsidiaries. Third, management functions outside the board are termed Outside CEO and Outside Officer if the director is also a CEO or an officer of another firm, respectively. Finally, non-corporate appointments are also defined. Interest groups identifies membership of interest groups (namely chambers of commerce) and Political affiliation are actual or former relations to government and political activities. Charity is membership of a charity (foundation or non-government organization), Advisory signifies advisory services (for example, memberships in scientific research groups), and Commission are memberships in commissions (for example, investment commissions).

\subsection{Control Variables}

We use several control variables to tackle omitted variable bias. Empirical evidence suggests that large, diversified and complex firms have more independent boards, while young, fastgrowing firms have insider-dominated boards (Boone et al. 2007; Coles, Daniel, and Naveen 2008; Linck, Netter, and Yang 2008; Lehn, Patro, and Zhao 2009). Older firms may have more severe agency problems (for example, empire building) while younger firms may benefit from lower information costs because firm-specific information is more important to them (Raheja 2005; Adams and Ferreira 2007). Furthermore, ownership structure characterizes the agency problems within a firm and influences the purpose of the board. For instance, the directors appointed to a firm which is controlled by one or a coalition of shareholders - as pre-dominant outside Anglo-Saxon countries - have to ensure that minority shareholder interests are respected. In some cases, the principal shareholders, the directors, and the executive board overlap largely where the standard stipulations on the independence of directors may be relaxed.

We include Board size which is the number of directors on the board (see Yermack 1996). Firm age is log of the number of years since the firm's incorporation plus 1 (see Pugliese and Wenstøp 2007). Ownership concentration measures ownership concentration by means of a 
Herfindahl-Hirschman Index. ${ }^{9}$ Sales growth is computed as the geometric mean of yearly sales growth over 4 periods (see Black and Khanna 2007). Diversification equals 1 if the firm has more than one business segment (and 0 otherwise). The corporate center as a business segment is excluded. This may be relevant since, according to Anderson et al. (2000), diversified firms have more outside directors. Firm size is log of the firm's total assets (total liabilities plus shareholder's equity) (Yermack 1996). Finally, we include industry and year fixed effects. Industries differ in their growth opportunities, competition, and industry regulation which all may affect the relationship between boards and firm performance (see e.g. Kole and Lehn 1999; Booth, Cornett, and Tehranian 2002; Boone et al. 2007).

\subsection{Summary Statistics and Univariate Analysis}

Table 1 provides descriptive statistics of the variables applied in this study. The first set of variables, the "independence variables", depicts that, on average, three quarters of the board members are independent, and 10 percent are executive directors. Both, former executives and directors with business relations make up around 7 percent of the directorships. Grey directors account for 14 percent of all directorships. The second set of variables, the "outside activity variables", presents the average number of outside engagements per director. In the mean board, each director has 3.51 outside appointments (total outside activities), but only 0.36 appointments in SPI boards. Hence, such SPI directorships represent about 16 percent of all directorships (= SPI directorships / (Chairmanships + Directorships)). 17 percent of all directors hold outside CEO positions, 25 percent outside executive officer positions, and 12 percent have political affiliations.

\section{$<$ INSERT TABLE 1 ABOUT HERE $>$}

The relationships between Tobin's Q and both Independence and Total outside activities are illustrated in Figure 1. The chart indicates that Tobin's Q is higher for firms in the lowest percentile group of both Independence and Total outside activities than for firms in the highest group. The figure suggests that higher independence and more outside activities are related to lower firm performance. However, the figure must be interpreted with care since omitted variables and other endogeneity issues are likely to drive these results.

\footnotetext{
${ }^{9}$ The index can assume values between 0 and 1 . In the one extreme case, if the index is 1 , all votes are combined in only one voting block where one has 100 percent of the voting rights. Conversely, if the index is 0 , then no one owns significant voting rights (over three percent).
} 
$<$ INSERT FIGURE 1 ABOUT HERE $>$

Our sample consists of 10,683 directorships of which 871 are held by executive directors. These directors exhibit different characteristics in comparison to non-executive directors. Table 4 presents statistical evidence that executive directors hold significantly fewer positions outside the firm in comparison to non-executive directors. Calling for more board independence will therefore potentially lead to boards' composed by directors who hold significantly more engagements. Furthermore, executive directors are younger, male and more likely to be foreigners than non-executive directors on average.

\section{$<$ INSERT TABLE 2 ABOUT HERE $>$}

\section{Empirical Analysis}

We evaluate the effect of board independence and outside activities on firm performance in several steps. Firstly, we use pooled ordinary least squares regression models with White (1980). We control for time trends using year dummies and for time-varying firm characteristics using a set of control variables. Secondly, we estimate the models with Driscoll-Kraay (1998) standard errors and cluster-robust standard errors. In addition, we use Fixed effects models to account for omitted variable bias. Thirdly, we tackle reverse causality with 2SLS. Fourthly, we examine the impact of the overall board structure on firm performance and decompose board independence and outside activities into several subelements. Finally, we assess the board's impact on board meetings.

\subsection{Ordinary Least Squares (OLS) Regression Models}

Table 3 presents the relation between independence and outside activity and Tobin's Q using pooled OLS regression models. Surprisingly, board independence is significantly negatively related to Tobin's Q (Column I). In contrast, there is no significant relationship between Tobin's Q and total outside activities (Column II). The same results hold when the effects of independence and outside activities on Tobin's Q are simultaneously estimated because independent boards are likely to be externally active boards (Column III).

$<$ INSERT TABLE 3 ABOUT HERE $>$ 


\subsection{Pooled, fixed and random effects regression models}

In the next step, we estimate the models using standard errors that are potentially better suited to the dataset. Driscoll-Kraay (1998) standard errors account for cross-sectional and serial correlation whereas cluster-robust Huber/White standard errors treat each firm as a cluster and account for within-firm correlation of the error terms. However, the results remain the same as when White (1980) standard errors are used (Table 4, Column I and II).

Endogeneity issues present several problems in corporate governance studies. ${ }^{10}$ Panel data enables tackling omitted variable bias by the use of firm fixed effects. Fixed effects control for time-invariant and unobserved firm characteristics. Therefore, within-firm changes are used to explain variation in the dependent variable (see e.g., Coles, Daniel and Naveen 2008). Indeed, several tests (Wooldridge's test [Wooldrige 2010], F test, Lagrange multiplier test) suggest that unobserved effects are important and that the models should be estimated using fixed effects.

\section{$<$ INSERT TABLE 4 ABOUT HERE $>$}

Table 4, Column III, indicates that board independence is no longer significantly related with Tobin's Q when firm fixed effects are included. However, corporate governance arrangements often change very slowly over time which poses problems when using fixed effects (see e.g. Gompers et al. 2003). Time variation for both independence and outside activity is indeed very low. The lagged variables of independence and total outside activities explain $79 \%$ and $88 \%$ respectively of their variation.

An alternative method is the use of Random effects models. Random effects models correct for within-firm correlation and the firm-specific effect is uncorrelated with the explanatory variable. However, Hausman (1978) test suggests that fixed effects models are preferred over random effects models.

Not only is the use of fixed effects problematic in cases where the variables of interest are quasi time-invariant, they also do not solve the causality problem. Independence and outside activities are still seen as exogenously determined.

\footnotetext{
${ }^{10}$ Endogeneity occurs in the presence of omitted variables bias, selection bias, misspecified or erroneous variables, measurement errors, and joint simultaneity.
} 


\section{3}

Instrumental Variables

Instrumental variables using 2SLS are commonly used to tackle causality problems (see e.g. Agrawal and Knoeber 1996). However, this method requires valid instruments. ${ }^{11}$ Valid instruments must be relevant and exogenous. Relevant instruments are significantly correlated with the endogenous variable conditional on the other variables (relevance condition). ${ }^{12}$ Exogenous instruments requires that they are determined outside of the model and not correlated with the error (exclusion condition). Hence, the selection of valid instruments is not trivial, especially in the context of corporate governance. The difficulty arises because variables that are related with the endogenous (governance) variable are most often other potential control variables. In addition, there were no fundamental legal changes in Switzerland during 2005 to 2012 which often serve as instruments (see e.g., Black, Jang and Kim 2006; Black and Kim 2012).

Our instruments are based on the reflections of Knyazeva, Knyazeva and Masulis (2013). They use the local supply of directors (measured as the number U.S. nonfinancial firms headquartered near the firm) as an instrument for independence. Board independence is higher when the pool of potential directors is larger. However, in this study, we use dummy variables for 10 different regions in Switzerland according to where the firm's headquarters are located. ${ }^{13}$ These regions include urban and rural/peripheral and central areas and cover different cultures (three different languages: German, French, and Italian; and two religions: Protestantism and Catholic). One third of the Swiss are living in the five largest agglomerations (Basel, Bern, Geneva, Lausanne and Zurich) and important international airports are located in Basel, Geneva and Zurich which potentially increases the international director pool. Furthermore, the overlap of people involved in political, economic, cultural activities and charity work is larger in some regions than in others which potentially affect the number of outside activities. Hence, economic, cultural and network effects are likely to affect in various degrees both board independence and total outside activity of directors. High

\footnotetext{
${ }^{11}$ As an example of reverse causation, think of a highly valued firm. Such a firm may be attractive to independent directors. In addition, this firm may have privileged resources and is not in need to seek directors who directly help in dealing with day-to-day business. As a result, a firm with a high Tobin's $\mathrm{Q}$ may choose a higher level of board independence, and not vice versa. Similar examples can be found for outside activities of board members where casual links cannot directly be established.

${ }^{12}$ So-called "weak instruments" have a low correlation with the endogenous variable; that is, they explain only a low variation in the endogenous variable that is not already described by the other exogenous variables. If the correlation between the instrument and the regressor is low, the standard errors of instrumental variables' estimators are high (Wooldridge 2010). Hence, an instrument must be significantly related to the endogenous variable in the reduced form.

${ }^{13}$ Basel (205), Bern (98), Central Switzerland (174), Geneva (90), Lausanne (98), Mittelland (93), St. Gallen (59), Ticino (21), Zurich (418) and other (238).
} 
F statistics of 53.8 for Independence and 77.8 for Total outside activities indicate the relevance of these instruments.

Furthermore, regional effects are most likely to be exogenous. Firstly, there are no arguments that the firm's headquarters influences a firm's performance. There are industrial clusters in some regions such as the financial centers in Zurich or Geneva or the pharmaceutical industry in Basel. However, industry effects are likely to absorb this correlation. Secondly, relocations of headquarters are very rare and happen only in very unusual circumstances. Almost all firms have been headquartered at the same place since their incorporation, therefore before their listing on the stock exchange and before directors have been selected. In addition, no firm is selling their products only locally and could therefore be affected by economic conditions in their region. After all, regional dummies do only affect firm performance via board composition.

\section{$<$ INSERT TABLE 5 ABOUT HERE $>$}

Table 5 shows first-stage regressions where regional dummies are included (Column I and II). We exclude year fixed effects from the first-stage regressions since corporate governance structures (including Independence and Total outside activities) are quasi time-invariant, especially in the period from 2005 to 2012. The results indicate that neither Independence nor Total outside activities is significantly related with Tobin's Q. However, the results depend on the validity of the instruments chosen and therefore, further examination of board independence and external commitments are needed.

\subsection{Independence and Outside Activities Re-Examined}

We next investigate which factors in a board's independence and in directors' outside activities affect firm performance.

Table 6 indicates that one-tier boards are positively related with Tobin's Q. We define One-tier boards as having at least one executive director (insider) on the board, while two-tier boards are defined as boards which have no executive directors on the board at all. Hence, the CEO is most likely to be a board member in a one-tier board system. Therefore, we evaluate the leadership structure in the next step. CEO is chairman is 1 if the chairman serves also as CEO of the firm (and 0 otherwise), and CEO is director is 1 if the CEO is an ordinary member of the board (and 0 otherwise). The results in Columns II and III reveal a positive 
relationship when the CEO is present on the board as an ordinary board member and no relationship in case of CEO duality.

\section{$<$ INSERT TABLE 6 ABOUT HERE $>$}

Subsequently, we decompose Independence and Total outside activities into sub-variables separately (Table 7 and Table 8). Firstly, we evaluate the components of board independence and examine in total 9 different variables. We include Total outside activities as a control. Hereby, Table 7, Column I and III, exhibits a positive and significant relationship of Executives and Former executives with firm performance. Executive directors (and former executives) may be closer to new industry trends and technologies than industry veterans or directors unfamiliar with the industry. Business relationships turn out to be unimportant in this regard. Family representatives on the board depicts a positive relationship. In contrast, more classical definitions such as Grey directors or Full independence are not significantly related to Tobin's Q.

\section{$<$ INSERT TABLE 7 ABOUT HERE $>$}

Secondly, we conduct the same procedure for outside activity. The number of all Total outside activities is split into 9 sub-variables. Similarly to above, we include Independence as a control. Table 9, Column I, presents variables that are related to executive activities. The results demonstrate that, while Executives is still positively associated with firm performance, executive positions outside the firm (both as outside CEO positions and outside officer positions) depict a negative relationship. Seemingly, investors question the due diligence of executives from firms other than their own. In contrast, there is a positive relationship between Chairmanships and Tobin's Q. All other external commitments, including SPI directorships which counts only directorships in listed Swiss firms and circumvents a bias in disclosure practice, are not significantly related to Tobin’s Q (Columns II, III, and IV).

$<$ INSERT TABLE 8 ABOUT HERE $>$ 
As mentioned before, board independence or outside activities may be indirectly related to Tobin's Q. The status of board members vis-à-vis the firm and their activities outside the board room can affect the time committed to the board. Vafeas (1999) reasons that meetings proxy for internal activity of the board. Jiraporn et al. (2009) show that directors with outside directorships are more frequently absent from meetings than others. For these reasons and given that independence is a measure of monitoring capacity, it can be expected that board independence and board internal activity are positively related. By contrast, if directors with outside activities do not devote enough time to the board, this variable should be negatively associated to board activity.

In order to test these questions empirically, we employ Poisson regressions with the Total number of all board meetings (including committee meetings) or the Total hours of all board meetings as its dependent variables. These are regressed on Full independence, Executives, Total outside activities, and SPI directorships. As a control variable, the Number of board committees is employed.

$<$ INSERT TABLE 9 ABOUT HERE $>$

$<$ INSERT TABLE 10 ABOUT HERE $>$

Table 9 displays summary statistics of meeting variables. In total and on average, board members met 17.61 times in one year, which gives a total board time of 71.38 hours. In comparison, the number of ordinary board meetings (excluding committee meetings) is 7.254 on average (median: 6), and the average length of an ordinary meeting is 5.522 hours (median: 5). The sample of Vafeas (1999) depicts 7.45 meetings on average. The results in Table 10 indicate that board membership of executive directors (insiders) is negatively related to board frequency and meeting duration, while the number of all outside activities, on average, positively affects the number of meetings, but negatively (insignificantly) affects the duration of all aggregated meetings. This suggests that meetings are not as necessary if there are more executive directors on the board. Insiders may use other opportunities to discuss the business processes. Furthermore, information may be transmitted more easily between the management and a board consisting of insiders, which reduces the need for meetings. The second result indicates that directors with outside activities are highly professional, indicating 
that they take board work seriously. Their seriousness may explain the number of outside activities they have on average.

\section{Conclusions}

The degree of independence and the number of outside activities of board members have been the subject of a broad range of empirical research. However, board independence is a vague term and hence a difficult descriptor for the board structure. The same is true for proxies of the board members' outside activities. Over the past few years, critics of firm governance have petitioned to promote an increased presence of independent directors on boards. Hence, they implicitly state that fewer independent directors hamper effective monitoring. In the words of Hermalin and Weisbach (2003), such commentators believe that boards are out of equilibrium and have to be adjusted in the shareholders' interest. Similarly, there is growing criticism regarding board members with multiple outside activities. These two issues are further complicated by the fact that they appear to be interrelated. The call for independent directors has led to an increasing number of 'professional' (outside) directors engaging in various outside activities.

Our results neither indicate that independence is positively related to Tobin's Q nor that external commitments are negatively related to it. Nevertheless, specific definitions of independence and outside activities do indicate significant relations. Executive directors and former executives are positively related to firm performance, while outside executives are negatively related to it. Furthermore, the relationship between representatives of family shareholders and firm value is positive. Investors seem to trust these directors more, which, in turn, results in higher firm valuation. Moreover, the frequency and duration of meetings is negatively affected by insiders because in some cases there may be more efficient ways of communication and decision making. Altogether, we find no strong empirical evidence that a higher proportion of independent directors or the number of outside activities would affect firm value.

\section{Acknowledgments}

I acknowledge the research grant by the Föderverein WWZ (B-119). I thank Robert Daines, Michel Habib, Kurt Schmidheiny, and David Yermack for helpful conversations and comments, and Hermione Miller-Moser for her editorial assistance. This paper is based on Chapter 5 of the $\mathrm{PhD}$ thesis by CV: "Corporate Governance in Switzerland", University of Basel, 2011. 


\section{References}

Adams, Renée B., and Daniel Ferreira. 2007. “A Theory of Friendly Boards.” The Journal of Finance 62(1):217-250.

Adams, Renée B., Benjamin E. Hermalin, and Michael S. Weisbach. 2010. "The Role of Boards of Directors in Corporate Governance: A Conceptual Framework and Survey.” Journal of Economic Literature 48(1):58-107.

Agrawal, Anup, and Charles R. Knoeber. 1996. "Firm Performance and Mechanisms to Control Agency Problems Between Managers and Shareholders.” The Journal of Financial and Quantitative Analysis 31(3):377-397.

Agrawal, Anup, and Charles R. Knoeber. 2001. "Do Some Outside Directors Play a Political Role?” The Journal of Law and Economics 44(1):179-198.

Ahn, Seoungpil, Pornsit Jiraporn, and Young Sang Kim. 2010. "Multiple Directorships and Acquirer Returns.” Journal of Banking and Finance 34(9):2011-2026.

Anderson, Ronald C., and David M. Reeb. 2004. "Board Composition: Balancing Family Influence in S\&P 500 Firms,” Administrative Science Quarterly 49(2):209-237.

Anderson, Ronald C., Thomas W. Bates, John M. Bizjak, and Michael L. Lemmon. 2000. “Corporate Governance and Firm Diversification.” Financial Management 29(1):5-22.

Baker, Malcolm, and Paul A. Gompers. 2003. "The Determinants of Board Structure at the Initial Public Offering.” The Journal of Law and Economics 46(2):569-598.

Baliga, B. Ram, R. Charles Moyer, and Ramesh S. Rao. 1996. “CEO Duality and Firm Performance: What's the Fuss?” Strategic Management Journal 17(1):41-53.

Baysinger, Barry D., and Henry N. Butler. 1985 “Corporate Governance and the Board of Directors: Performance Effects of Changes in Board Composition.” Journal of Law, Economics, and Organization 1(1):101-124. 
Beiner, Stefan, Wolfgang Drobetz, Markus M. Schmid, and Heinz Zimmermann. 2006. “An Integrated Framework of Corporate Governance and Firm Valuation.” European Financial Management 12(2):249-283.

Bhagat, Sanjai, and Bernard Black. 1999. “The Uncertain Relationship between Board Composition and Firm Performance.” Business Lawyer 54:921-964.

Bhagat, Sanjai, and Bernard Black. 2002. "The Non-Correlation between Board Independence and Long-Term Firm Performance.” Journal of Corporate Law 27(2):231-274.

Bhagat, Sanjai, and Brian Bolton. 2008. “Corporate Governance and Firm Performance.” Journal of Corporate Finance 14(3):257-273.

Black, Bernard S., and Vikramaditya S. Khanna, 2007. “Can corporate governance reforms increase firm market values? Event study evidence from India.” Journal of Empirical Legal Studies, 4(4):749-796.

Black, Bernard S., Jang, Hasung, and Woochan Kim. 2006. "Does corporate governance predict firms' market values? Evidence from Korea.” Journal of Law, Economics, and Organization, 22(2):366-413.

Black, Bernard S., and Woochan Kim. 2012. "The effect of board structure on firm value: A multiple identification strategies approach using Korean data.” Journal of Financial Economics, 104(1):203-226.

Boone, Audra L., Laura Casares Field, Jonathan M. Karpoff, and Charu G. Raheja. 2007. “The Determinants of Corporate Board Size and Composition: An Empirical Analysis.” Journal of Financial Economics 85(1):66-101.

Booth, James R., Marcia Millon Cornett, and Hassan Tehranian. 2002. “Boards of Directors, Ownership, and Regulation.” Journal of Banking and Finance 26(10):1973-1996.

Brickley, James A., Jeffrey L. Coles, and Gregg Jarrell. 1997. “Leadership Structure: Separating the CEO and Chairman of the Board.” Journal of Corporate Finance 3(3):189200. 
Cai, Jie, Jacqueline L. Garner, and Ralph A. Walkling. 2009. “Electing Directors.” The Journal of Finance 64(5):2389-2421.

Cohen, Lauren, Frazzini, Andrea, and Christopher J. Malloy. 2012. "Hiring cheerleaders: Board appointments of “independent” directors.” Management Science, 58(6):1039-1058.

Coles, Jeffrey L., Naveen D. Daniel, and Lalitha Naveen. 2008. “Boards: Does One Size Fit All?” Journal of Financial Economics 87(2):329-356.

Conyon, Martin J., and Laura E. Read. 2006. “A Model of the Supply of Executives for Outside Directorships.” Journal of Corporate Finance 12(3):645-659.

Dalton, Dan R., Catherine M. Daily, Alan E. Ellstrand, and Jonathan L. Johnson. 1998. "Meta-Analytic Reviews of Board Composition, Leadership Structure, and Financial Performance.” Strategic Management Journal 19(3):269-290.

De Jong, Abe, Hooghiemstra, Reggy, and Marcel Van Rinsum. 2014. “To Accept or Refuse an Offer to Join the Board: Dutch Evidence.” Long Range Planning 47(5):262-276.

Fahlenbrach, Rüdiger, Angie Low, and René M. Stulz. 2010 “Why Do Firms Appoint CEOs as Outside Directors?” Journal of Financial Economics 97(1):12-32.

Faleye, Olubunmi. 2007. "Does One Hat Fit All? The Case of Corporate Leadership Structure.” Journal of Management and Governance 11(3):239-259.

Fama, Eugene F. 1980. “Agency Problems and the Theory of the Firm.” The Journal of Political Economy 88(2):288-307.

Fama, Eugene F., and Michael C. Jensen. 1983 “Separation of Ownership and Control.” The Journal of Law and Economics 26(2):301-325.

Ferris, Stephen P., Murali Jagannathan, and A. C. Pritchard. 2003. "Too Busy to Mind the Business? Monitoring by Directors with Multiple Board Appointments.” Journal of Finance 58(3):1087-1111.

Fich, Eliezer M. 2005. “Are Some Outside Directors Better than Others? Evidence from Director Appointments by Fortune 1000 Firms.” The Journal of Business 78(5):1943-1972. 
Fich, Eliezer M., and Anil. Shivdasani. 2006. “Are Busy Boards Effective Monitors?” The Journal of Finance 61(2):689-724.

Fich, Eliezer M., and Anil Shivdasani. 2007. "Financial Fraud, Director Reputation, and Shareholder Wealth.” Journal of Financial Economics 86(2):306-336.

Goldman, Eitan, Jörg Rocholl, and Jongil So. 2009. “Do Politically Connected Boards Affect Firm Value?” Review of Financial Studies 22(6):2331-2360.

Gordon, Jeffrey N. 2007. “The Rise of Independent Directors in the United States, 19502005: Of Shareholder Value and Stock Market Prices.” Stanford Law Review 59:1465-1791.

Hausman, J.A. (1978), Specification tests in econometrics, Econometrica 46, 1251-1271.

Helland, Eric, and Michael Sykuta. 2004. "Regulation and the Evolution of Corporate Boards: Monitoring, Advising, or Window Dressing?” The Journal of Law and Economics 47(1):167193.

Hermalin, Benjamin E., and Michael S. Weisbach. 1991. "The Effects of Board Composition and Direct Incentives on Firm Performance.” Financial Management 20(4):101-112.

Hermalin, Benjamin E., and Michael S. Weisbach. 2003. "Boards of Directors as an Endogenously Determined Institution: A Survey of the Economic Literature.” Economic Policy Review 9(1):7-26.

Hillman, Amy J. 2005. "Politicians on the Board of Directors: Do Connections Affect the Bottom Line?” Journal of Management 31(3):464-481.

Jensen, Michael C., and William H. Meckling. 1976. "Theory of the Firm: Managerial Behavior, Agency Costs and Ownership Structure.” Journal of Financial Economics 3(4):305-360.

Jiraporn, Pornsit, Wallace N. Davidson III, Peter DaDalt, and Yixi Ning. 2009. “Too Busy to Show Up? An Analysis of Directors’ Absences.” The Quarterly Review of Economics and Finance 49(3):1159-1171. 
Jiraporn, Pornsit, Young Sang Kim, and Wallace N. Davidson III. 2008. “Multiple Directorships and Corporate Diversification.” Journal of Empirical Finance 15(3):418-435.

Klein, April. 1998. "Firm Performance and Board Committee Structure,” The Journal of Law and Economics 41(1):275-304.

Kole, Stacey R., and Kenneth M. Lehn. 1999. "Deregulation and the Adaptation of Governance Structure: The Case of the U.S. Airline Industry.” Journal of Financial Economics 52(1):79-117.

Lehn, Kenneth M., Sukesh Patro, and Mengxin Zhao. 2009. "Determinants of the Size and Composition of US Corporate Boards: 1935-2000.” Financial Management 38(4):747-780.

Linck, James S., Jeffry M. Netter, and Tina Yang. 2008. “The Determinants of Board Structure.” Journal of Financial Economics 87(2):308-328.

Loderer, Claudio, and Urs Peyer. 2002. “Board Overlap, Seat Accumulation and Share Prices.” European Financial Management 8(2):165-192.

Lorsch, Jay W., and Elizabeth MacIver. 1989. Pawns or Potentates: The Reality of America's Corporate Boards. Cambridge: Harvard Business Press.

Masulis, Ronald W., and Shawn Mobbs. 2011. “Are all Inside Directors the Same? Evidence from the External Directorship Market.” The Journal of Finance 66(3):823-872.

Masulis, Ronald W., and Shawn Mobbs. 2014. “Independent director incentives: Where do talented directors spend their limited time and energy?.“ Journal of Financial Economics 111(2):406-429.

Nguyen, Bang Dang, and Kasper Meisner Nielsen. 2010. „The Value of Independent Directors: Evidence from Sudden Deaths.” Journal of Financial Economics 98(3):550-567.

Perry, Tod, and Urs Peyer. 2005. “Board Seat Accumulation by Executives: A Shareholder’s Perspective.” The Journal of Finance 60(4):2083-2123.

Pfeffer, Jeffrey, and Gerald R. Salancik. 1978. The External Control of Organizations. New York: Harper and Row. 
Pugliese, Amedeo, and Pingying Zhang Wenstøp, (2007). “Board Members’ Contribution to Strategic Decision-making in Small Firms.” Journal of Management \& Governance 11(4):383-404.

Raheja, Charu G. 2005. "Determinants of Board Size and Composition: A Theory of Corporate Boards.” Journal of Financial and Quantitative Analysis 40(2):283-306.

Schmid, Markus M., and Heinz Zimmermann. 2008. "Leadership Structure and Corporate Governance in Switzerland.” Journal of Applied Corporate Finance 20(1):109-120.

Shivdasani, Anil, and David Yermack. 1999. "CEO Involvement in the Selection of New Board Members: An Empirical Analysis.” The Journal of Finance 54(5):1829-1853.

Spencer Stuart. 2010. Board Index.

Vafeas, Nikos. 1999. “Board Meeting Frequency and Firm Performance.” Journal of Financial Economics 53(1):113-142.

Verbeek, Marno. 2008. A Guide to Modern Econometrics. 2nd ed. Chichester: Wiley and Sons.

Volonté, Christophe (2014). Regulation and the evolution of the board of directors in Switzerland during the last 25 years, Working paper.

Weisbach, Michael S. 1988. “Outside Directors and CEO Turnover.” Journal of Financial Economics 20(1-2):431-460.

White, Halbert. 1980. “A Heteroskedasticity-Consistent Covariance Matrix Estimator and a Direct Test for Heteroskedasticity.” Econometrica: Journal of the Econometric Society 48(4):817-838.

Wooldridge, Jeffrey M. 2010. Econometric Analysis of Cross Section and Panel Data. 2nd ed. Cambridge: The MIT press.

Yermack, David. 1996. "Higher market Valuation of Companies with a Small Board of Directors.” Journal of Financial Economics 40(2):185-211. 
Yermack, David. 2004. "Remuneration, Retention, and Reputation Incentives for Outside Directors.” The Journal of Finance 59(5):2281-2308.

Yermack, David. 2006. “Board Members and Company Value.” Financial Markets and Portfolio Management 20(1):33-47.

\section{Figure Legends}

Figure 1: Comparison of Board Independence and Outside Activities with Tobin's Q

\section{Figures}

Figure 1: Comparison of Board Independence and Outside Activities with Tobin's Q

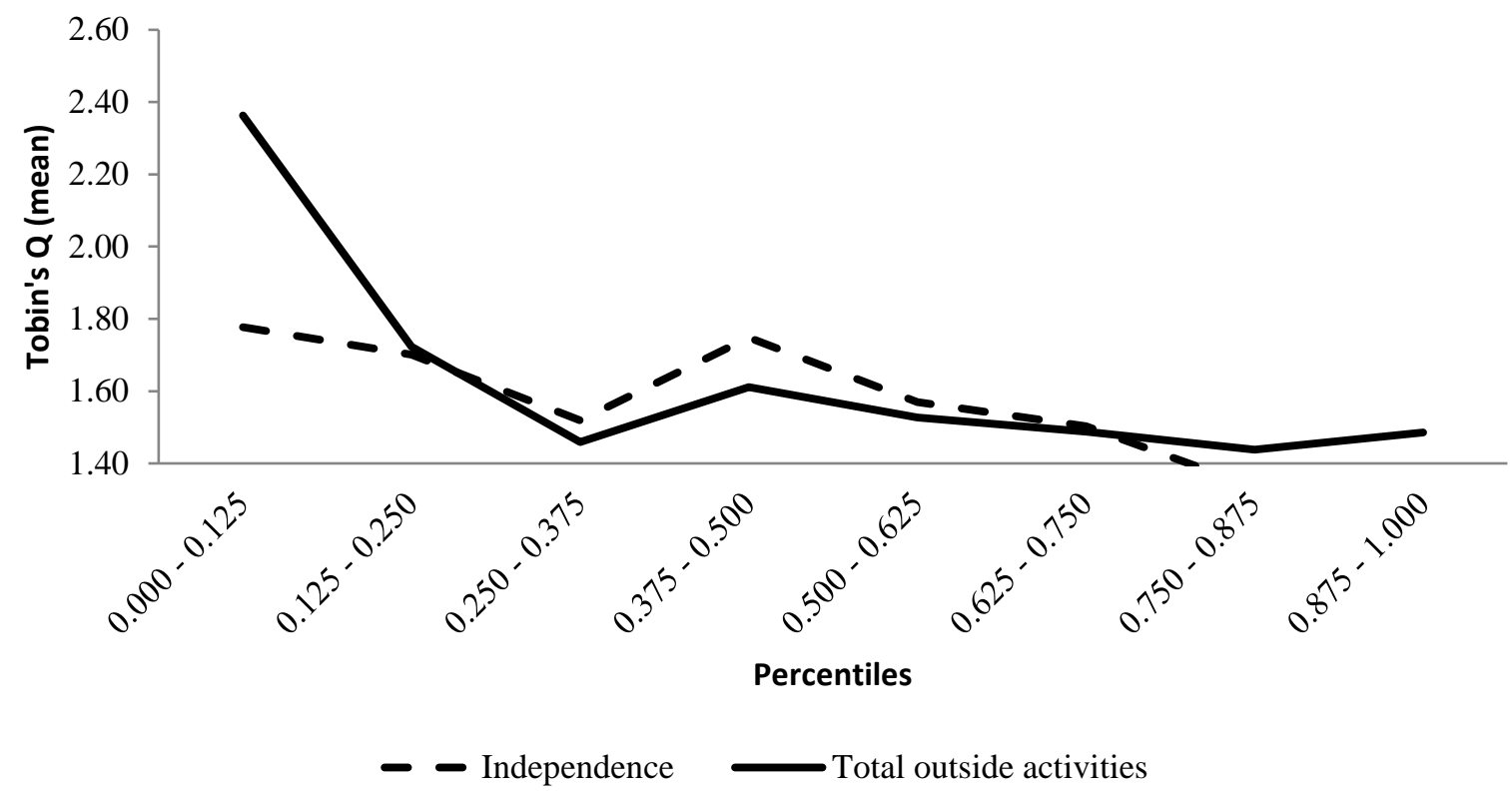


Tables

Table 1

\section{SUMMARY STATISTICS}

\begin{tabular}{|c|c|c|c|c|c|c|c|c|c|c|c|c|c|}
\hline Variable & Mean & Median & Min & Max & s.d. & 2005 & 2006 & 2007 & 2008 & 2009 & 2010 & 2011 & 2012 \\
\hline Number of firms & \multicolumn{5}{|c|}{1,494} & 178 & 184 & 191 & 194 & 191 & 191 & 185 & 180 \\
\hline \multicolumn{14}{|l|}{ Performance variable } \\
\hline Tobin's Q & 1.56 & 1.26 & 0.74 & 4.49 & 0.78 & 1.61 & 1.82 & 1.78 & 1.28 & 1.49 & 1.61 & 1.42 & 1.49 \\
\hline \multicolumn{14}{|l|}{ Independence variables } \\
\hline Independence & 0.76 & 0.80 & 0.00 & 1.00 & 0.21 & 0.76 & 0.76 & 0.75 & 0.75 & 0.76 & 0.77 & 0.76 & 0.77 \\
\hline Full Independence & 0.46 & 0.44 & 0.00 & 1.00 & 0.26 & 0.48 & 0.46 & 0.45 & 0.45 & 0.45 & 0.45 & 0.45 & 0.45 \\
\hline Grey & 0.14 & 0.13 & 0.00 & 1.00 & 0.16 & 0.13 & 0.13 & 0.14 & 0.15 & 0.14 & 0.14 & 0.15 & 0.14 \\
\hline Executives & 0.10 & 0.00 & 0.00 & 1.00 & 0.15 & 0.11 & 0.11 & 0.11 & 0.10 & 0.10 & 0.09 & 0.09 & 0.08 \\
\hline Former executives & 0.08 & 0.00 & 0.00 & 1.00 & 0.12 & 0.08 & 0.08 & 0.08 & 0.08 & 0.08 & 0.08 & 0.09 & 0.08 \\
\hline Business relationships & 0.07 & 0.00 & 0.00 & 0.83 & 0.13 & 0.06 & 0.06 & 0.07 & 0.08 & 0.07 & 0.06 & 0.07 & 0.06 \\
\hline Long tenure & 0.28 & 0.25 & 0.00 & 1.00 & 0.26 & 0.26 & 0.27 & 0.27 & 0.27 & 0.28 & 0.29 & 0.29 & 0.29 \\
\hline Blockholding directors & 0.07 & 0.00 & 0.00 & 0.67 & 0.13 & 0.07 & 0.08 & 0.08 & 0.08 & 0.08 & 0.07 & 0.06 & 0.06 \\
\hline Shareholder representatives & 0.13 & 0.00 & 0.00 & 1.00 & 0.22 & 0.12 & 0.12 & 0.13 & 0.12 & 0.14 & 0.13 & 0.14 & 0.15 \\
\hline Family representatives & 0.08 & 0.00 & 0.00 & 1.00 & 0.16 & 0.07 & 0.08 & 0.08 & 0.08 & 0.08 & 0.08 & 0.08 & 0.08 \\
\hline \multicolumn{14}{|l|}{ Outside activity variables } \\
\hline Total outside activities & 3.51 & 3.33 & 0.00 & 13.33 & 1.65 & 3.41 & 3.44 & 3.41 & 3.47 & 3.53 & 3.59 & 3.59 & 3.61 \\
\hline SPI directorships & 0.36 & 0.29 & 0.00 & 1.80 & 0.35 & 0.37 & 0.37 & 0.38 & 0.39 & 0.38 & 0.36 & 0.33 & 0.30 \\
\hline Chairmanships & 0.53 & 0.43 & 0.00 & 4.00 & 0.46 & 0.54 & 0.53 & 0.55 & 0.54 & 0.54 & 0.53 & 0.52 & 0.50 \\
\hline Directorships & 1.69 & 1.57 & 0.00 & 7.33 & 1.00 & 1.65 & 1.68 & 1.65 & 1.67 & 1.68 & 1.73 & 1.71 & 1.72 \\
\hline
\end{tabular}




\begin{tabular}{|c|c|c|c|c|c|c|c|c|c|c|c|c|c|}
\hline Outside CEO positions & 0.17 & 0.14 & 0.00 & 1.25 & 0.18 & 0.15 & 0.15 & 0.16 & 0.16 & 0.18 & 0.17 & 0.18 & 0.19 \\
\hline Outside officer positions & 0.25 & 0.20 & 0.00 & 1.25 & 0.22 & 0.23 & 0.23 & 0.23 & 0.24 & 0.24 & 0.26 & 0.28 & 0.30 \\
\hline Interest group members & 0.24 & 0.17 & 0.00 & 1.43 & 0.28 & 0.22 & 0.23 & 0.22 & 0.22 & 0.24 & 0.25 & 0.26 & 0.26 \\
\hline Politically affiliated members & 0.12 & 0.00 & 0.00 & 0.92 & 0.17 & 0.13 & 0.12 & 0.12 & 0.12 & 0.12 & 0.11 & 0.11 & 0.11 \\
\hline Charity members & 0.32 & 0.17 & 0.00 & 3.13 & 0.45 & 0.32 & 0.31 & 0.31 & 0.32 & 0.34 & 0.34 & 0.32 & 0.31 \\
\hline Advisory appointments & 0.17 & 0.08 & 0.00 & 1.83 & 0.26 & 0.16 & 0.15 & 0.14 & 0.15 & 0.17 & 0.18 & 0.19 & 0.19 \\
\hline Commission members & 0.04 & 0.00 & 0.00 & 1.33 & 0.12 & 0.04 & 0.03 & 0.03 & 0.04 & 0.04 & 0.05 & 0.05 & 0.04 \\
\hline \multicolumn{14}{|l|}{ Control Variables } \\
\hline Board size & 7.1 & 7.0 & 2.0 & 20.0 & 2.7 & 7.3 & 7.2 & 7.2 & 7.1 & 7.1 & 7.1 & 7.0 & 7.1 \\
\hline Firm age (years) & 74.7 & 58.0 & 1.0 & 494.0 & 62.7 & 75.9 & 74.8 & 73.4 & 73.1 & 73.9 & 74.9 & 74.8 & 76.8 \\
\hline Ownership concentration & 0.19 & 0.11 & 0.00 & 1.00 & 0.21 & 0.19 & 0.19 & 0.19 & 0.20 & 0.20 & 0.20 & 0.19 & 0.20 \\
\hline Sales Growth & 0.05 & 0.03 & -0.32 & 1.53 & 0.19 & 0.05 & 0.09 & 0.11 & 0.11 & 0.05 & 0.04 & -0.01 & -0.01 \\
\hline Diversification & 0.71 & - & - & - & 0.45 & 0.72 & 0.72 & 0.71 & 0.71 & 0.70 & 0.70 & 0.71 & 0.72 \\
\hline Firm size (in Millions CHF) & 26,630 & 873 & 0 & $2,393,000$ & 160,241 & 29,220 & 30,570 & 29,940 & 26,540 & 23,160 & 23,210 & 25,180 & 25,420 \\
\hline
\end{tabular}

NOTE. - The sample consists of 1,494 firm-year observations. The table presents mean, median, minimum (Min), maximum (Max), and standard deviation (s.d.) for each variable. 
Table 2

DIRECTOR CHARACTERISTICS

\begin{tabular}{|c|c|c|c|c|}
\hline \multirow{4}{*}{$\begin{array}{l}\text { Observations } \\
\text { in } \%\end{array}$} & & Executive & Non-Executive & \multirow{4}{*}{$\begin{array}{c}\text { t-test/ } \\
\text { (Wilcoxon-test) }\end{array}$} \\
\hline & All & Directors & Directors & \\
\hline & 10,683 & 871 & 9,812 & \\
\hline & $100.00 \%$ & $8.15 \%$ & $91.85 \%$ & \\
\hline Age & 57.7 & 54.5 & 58.0 & $* * * /(* * *)$ \\
\hline Tenure & 7.6 & 9.5 & 7.4 & $* * * /(* * *)$ \\
\hline Female & $6.7 \%$ & $3.8 \%$ & $7.0 \%$ & $* * * /(* * *)$ \\
\hline Foreigner & $27.9 \%$ & $34.9 \%$ & $27.3 \%$ & $* * * /(* * *)$ \\
\hline Total outside activities & 3.6 & 2.1 & 3.8 & $* * * /(* * *)$ \\
\hline SPI directorships & 0.4 & 0.2 & 0.4 & $* * * /(* * *)$ \\
\hline Chairmanships & 0.5 & 0.3 & 0.6 & $* * * /(* * *)$ \\
\hline Directorships & 1.7 & 1.0 & 1.7 & $* * * /(* * *)$ \\
\hline Outside CEO positions & 0.2 & 0.1 & 0.2 & $* * * /(* * *)$ \\
\hline Outside officer positions & 0.2 & 0.1 & 0.3 & $* * * /(* * *)$ \\
\hline Interest group members & 0.3 & 0.2 & 0.3 & $* * * /(* *)$ \\
\hline Politically affiliated members & 0.1 & 0.1 & 0.2 & $* * * /(* * *)$ \\
\hline Advisory appointments & 0.2 & 0.1 & 0.2 & $* * /(* * *)$ \\
\hline Commission members & 0.0 & 0.0 & 0.0 & $* * /(* * *)$ \\
\hline Blockholding directors & $5.7 \%$ & $24.1 \%$ & $4.1 \%$ & $* * * /(* * *)$ \\
\hline Family representatives & $7.1 \%$ & $18.4 \%$ & $6.1 \%$ & $* * * /(* * *)$ \\
\hline Shareholder representatives & $14.3 \%$ & $8.6 \%$ & $14.8 \%$ & $* * * /(* * *)$ \\
\hline
\end{tabular}

NOTE. - The table presents comparisons between executive directors and non-executive directors boards. The equality of medians is tested using a Wilcoxon rank sum test with continuity correction and the quality of means is tested using a Welch Two Sample t-test.

$* p<.10$.

$* * p<.05$.

$* * * p<.01$. 
Table 3

INDEPENDENCE AND OUTSIDE ACTIVITIES

\begin{tabular}{|c|c|c|c|c|c|c|}
\hline \multirow{3}{*}{$\begin{array}{l}\text { Independent } \\
\text { Variables } \\
\text { (Intercept) }\end{array}$} & \multicolumn{5}{|c|}{ Dependent Variable: Tobin's Q } & \multirow{4}{*}{$(* *)$} \\
\hline & (I) & & (II) & & (III) & \\
\hline & 1.50436 & $(* *)$ & 1.28808 & $(* *)$ & 1.50312 & \\
\hline & $(0.592)$ & & $(0.590)$ & & $(0.592)$ & \\
\hline \multirow[t]{2}{*}{ Independence } & -0.50733 & $(* * *)$ & & & -0.49849 & $(* * *)$ \\
\hline & $(0.194)$ & & & & $(0.185)$ & \\
\hline \multirow[t]{2}{*}{ Total outside activities } & & & -0.01759 & & -0.00604 & \\
\hline & & & $(0.023)$ & & $(0.022)$ & \\
\hline \multirow[t]{2}{*}{$\log$ Board size } & 0.11499 & & 0.03938 & & 0.11216 & \\
\hline & $(0.123)$ & & $(0.131)$ & & $(0.122)$ & \\
\hline \multirow[t]{2}{*}{ log Firm age } & -0.02558 & & -0.03077 & & -0.02454 & \\
\hline & $(0.045)$ & & $(0.047)$ & & $(0.045)$ & \\
\hline \multirow[t]{2}{*}{ Ownership concentration } & -0.17339 & & -0.13441 & & -0.16839 & \\
\hline & $(0.165)$ & & $(0.174)$ & & $(0.170)$ & \\
\hline \multirow[t]{2}{*}{ Sales Growth } & 0.14469 & & 0.20396 & & 0.14667 & \\
\hline & $(0.195)$ & & $(0.195)$ & & $(0.194)$ & \\
\hline \multirow[t]{2}{*}{ Diversification } & -0.17819 & & -0.19798 & $(*)$ & -0.17945 & \\
\hline & $(0.113)$ & & $(0.115)$ & & $(0.113)$ & \\
\hline \multirow[t]{2}{*}{$\log$ Firm size } & 0.02925 & & 0.03050 & & 0.03063 & \\
\hline & $(0.030)$ & & $(0.032)$ & & $(0.031)$ & \\
\hline Industry & included & & included & & included & \\
\hline Year & included & & included & & included & \\
\hline Multiple $\mathrm{R}^{2}$ & 0.3341 & & 0.3204 & & 0.3342 & \\
\hline Adjusted $\mathrm{R}^{2}$ & 0.3274 & & 0.3140 & & 0.3273 & \\
\hline F-statistic & 25.3 & $* * *$ & 23.8 & $* * *$ & 24.5 & $* * *$ \\
\hline
\end{tabular}

NOTE. - The table presents pooled OLS regression coefficient estimates for independence and outside activity variables. The sample consists of 1,494 firm-year observations. White (1980) standard errors are reported in parentheses.

$* p<.10$.

$* * p<.05$.

$* * * p<.01$. 
Table 4

POOLED, FIXED, AND RANDOM EFFECTS: INDEPENDENCE AND OUTSIDE ACTIVITIES

\begin{tabular}{|c|c|c|c|c|c|c|c|c|}
\hline Independent & & & Depen & ent Var & le: Tobin's Q & & & \\
\hline Variables & (I) & & (II) & & (III) & & (IV) & \\
\hline (Intercept) & 1.50312 & $(* * *)$ & 1.50312 & $(* * *)$ & & & 2.63229 & $(* * *)$ \\
\hline & $(0.053)$ & & $(0.245)$ & & & & $(0.466)$ & \\
\hline Independence & -0.49849 & $(* * *)$ & -0.49849 & $(* * *)$ & 0.00812 & & -0.12221 & \\
\hline & $(0.052)$ & & $(0.090)$ & & $(0.100)$ & & (0.097) & \\
\hline Total outside & -0.00604 & & -0.00604 & & 0.00344 & & 0.00989 & \\
\hline & (0.007) & & $(0.011)$ & & (0.018) & & $(0.016)$ & \\
\hline $\log$ Board size & 0.11216 & $(* *)$ & 0.11216 & & -0.00502 & & 0.01520 & \\
\hline & $(0.045)$ & & $(0.070)$ & & $(0.075)$ & & (0.073) & \\
\hline log Firm age & -0.02454 & & -0.02454 & & -0.40280 & $(* * *)$ & -0.06138 & \\
\hline & $(0.015)$ & & (0.019) & & $(0.096)$ & & (0.039) & \\
\hline $\begin{array}{l}\text { Ownership } \\
\text { concentration }\end{array}$ & -0.16839 & $(*)$ & -0.16839 & $(*)$ & 1.12112 & $(* * *)$ & 0.56051 & $(* * *)$ \\
\hline & $(0.096)$ & & $(0.090)$ & & (0.195) & & $(0.152)$ & \\
\hline Sales Growth & 0.14667 & & 0.14667 & & 0.19723 & $(* *)$ & 0.14676 & $(*)$ \\
\hline & $(0.126)$ & & $(0.100)$ & & $(0.081)$ & & $(0.081)$ & \\
\hline Diversification & -0.17945 & $(* * *)$ & -0.17945 & $(* * *)$ & -0.40450 & $(* *)$ & -0.17285 & $(*)$ \\
\hline & $(0.036)$ & & $(0.045)$ & & $(0.190)$ & & $(0.092)$ & \\
\hline $\log$ Firm size & 0.03063 & $(* *)$ & 0.03063 & $(* *)$ & -0.30917 & $(* * *)$ & -0.06894 & $(* * *)$ \\
\hline & $(0.015)$ & & $(0.014)$ & & $(0.035)$ & & $(0.023)$ & \\
\hline Industry & included & & included & & excluded & & included & \\
\hline Year & included & & included & & included & & included & \\
\hline Multiple $\mathrm{R}^{2}$ & 0.3342 & & 0.3342 & & 0.2676 & & 0.2265 & \\
\hline Adjusted $\mathrm{R}^{2}$ & 0.3273 & & 0.3273 & & 0.2288 & & 0.2218 & \\
\hline F-statistic & 24.5 & $* * *$ & 24.5 & $* * *$ & 31.1 & $* * *$ & 14.3 & $* * *$ \\
\hline Method & Pooling & & Pooling & & $\begin{array}{l}\text { Two-ways } \\
\text { Fixed effects }\end{array}$ & & Random & \\
\hline Sta & Driscoll- & & Cluster-robust & & Cluster-robust & & Cluster-robust & \\
\hline & Kraay & & Huber/White & & Huber/White & & Huber/White & \\
\hline
\end{tabular}

NOTE. - The table presents regression coefficient estimates for independence and outside activity variables. The sample consists of 1,494 firm-year observations. Driscoll-Kraay (1998) or cluster-robust standard errors are reported in parentheses.

$* p<.10$.

$* * p<.05$.

$* * * p<.01$. 
Table 5

2SLS: INDEPENDENCE AND OUTSIDE ACTIVITIES

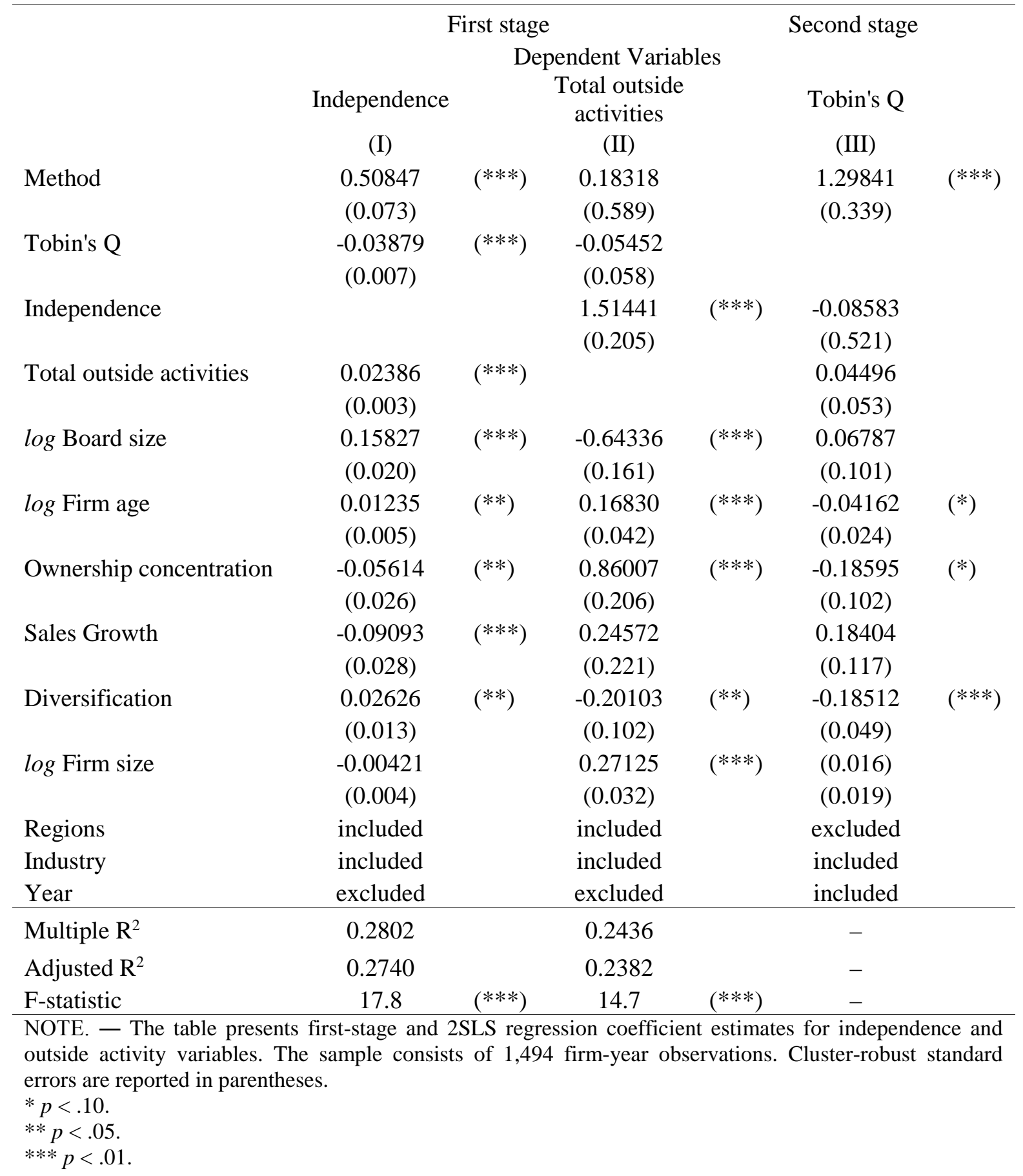


Table 6

\section{BOARD STRUCTURE}

\begin{tabular}{|c|c|c|c|c|c|c|}
\hline \multirow{4}{*}{$\begin{array}{l}\text { Independent } \\
\text { Variables } \\
\text { (Intercept) }\end{array}$} & \multicolumn{5}{|c|}{ Dependent Variable: Tobin's Q } & \multirow{4}{*}{$(* * *)$} \\
\hline & (I) & & (II) & & (III) & \\
\hline & 1.23281 & $(* * *)$ & 1.27415 & $(* * *)$ & 1.23268 & \\
\hline & $(0.245)$ & & $(0.245)$ & & $(0.244)$ & \\
\hline \multirow[t]{2}{*}{ One tier } & 0.09194 & $(* *)$ & & & & \\
\hline & $(0.038)$ & & & & & \\
\hline \multirow[t]{2}{*}{ CEO duality } & & & 0.04301 & & & \\
\hline & & & $(0.055)$ & & & \\
\hline \multirow[t]{2}{*}{ CEO is director } & & & & & 0.14126 & $(* * *)$ \\
\hline & & & & & $(0.047)$ & \\
\hline \multirow[t]{2}{*}{ Total outside activities } & -0.01488 & & -0.01761 & & -0.01473 & \\
\hline & $(0.011)$ & & $(0.011)$ & & $(0.011)$ & \\
\hline \multirow[t]{2}{*}{$\log$ Board size } & 0.03335 & & 0.04390 & & 0.01604 & \\
\hline & $(0.069)$ & & $(0.069)$ & & $(0.069)$ & \\
\hline \multirow[t]{2}{*}{$\log$ Firm age } & -0.02741 & & -0.03063 & & -0.02518 & \\
\hline & $(0.019)$ & & $(0.019)$ & & $(0.019)$ & \\
\hline \multirow[t]{2}{*}{ Ownership concentration } & -0.14008 & & -0.13491 & & -0.12958 & \\
\hline & $(0.091)$ & & $(0.091)$ & & $(0.091)$ & \\
\hline \multirow[t]{2}{*}{ Sales Growth } & 0.18813 & $(*)$ & 0.20817 & $(* *)$ & 0.16114 & \\
\hline & $(0.101)$ & & $(0.101)$ & & $(0.102)$ & \\
\hline \multirow[t]{2}{*}{ Diversification } & -0.19088 & $(* * *)$ & -0.19678 & $(* * *)$ & -0.18253 & $(* * *)$ \\
\hline & $(0.045)$ & & $(0.045)$ & & $(0.046)$ & \\
\hline \multirow[t]{2}{*}{$\log$ Firm size } & 0.03167 & $(* *)$ & 0.03023 & $(* *)$ & 0.03370 & $(* *)$ \\
\hline & $(0.014)$ & & $(0.014)$ & & $(0.014)$ & \\
\hline Industry & included & & included & & included & \\
\hline Year & included & & included & & included & \\
\hline Multiple $\mathrm{R}^{2}$ & 0.3231 & & 0.3207 & & 0.3245 & \\
\hline Adjusted $\mathrm{R}^{2}$ & 0.3164 & & 0.3140 & & 0.3178 & \\
\hline F-statistic & 23.3 & $* * *$ & 23.0 & $* * *$ & 23.4 & $* * *$ \\
\hline \multicolumn{7}{|c|}{$\begin{array}{l}\text { NOTE. - The table presents regression coefficient estimates for board structure } \\
\text { variables. The sample consists of } 1,494 \text { firm-year observations. Cluster-robust } \\
\text { standard errors are reported in parentheses. } \\
* p<.10 \text {. } \\
* * p<.05 \text {. } \\
* * * p<.01 \text {. }\end{array}$} \\
\hline
\end{tabular}


Table 7

INDEPENDENCE

\begin{tabular}{|c|c|c|c|c|c|c|c|c|}
\hline \multirow{4}{*}{$\begin{array}{l}\text { Independent } \\
\text { Variables } \\
\text { (Intercept) }\end{array}$} & \multicolumn{7}{|c|}{ Dependent Variable: Tobin's Q } & \multirow{4}{*}{$(* * *)$} \\
\hline & (I) & & (II) & & (III) & & (IV) & \\
\hline & 0.83070 & $(* * *)$ & 1.27120 & $(* * *)$ & 0.95666 & $(* * *)$ & 1.33590 & \\
\hline & $(0.248)$ & & $(0.245)$ & & $(0.253)$ & & $(0.247)$ & \\
\hline \multirow[t]{2}{*}{ Executives } & 0.89878 & $(* * *)$ & & & 0.92266 & $(* * *)$ & & \\
\hline & $(0.131)$ & & & & $(0.131)$ & & & \\
\hline \multirow[t]{2}{*}{ Former executives } & 0.69156 & $(* * *)$ & & & 0.65489 & $(* * *)$ & & \\
\hline & $(0.150)$ & & & & $(0.151)$ & & & \\
\hline \multirow[t]{2}{*}{ Business relationships } & -0.18005 & & & & -0.12241 & & & \\
\hline & $(0.136)$ & & & & $(0.136)$ & & & \\
\hline \multirow[t]{2}{*}{ Grey } & & & 0.13370 & & & & & \\
\hline & & & $(0.110)$ & & & & & \\
\hline \multirow[t]{2}{*}{ Long tenure } & & & & & -0.13893 & $(*)$ & & \\
\hline & & & & & $(0.072)$ & & & \\
\hline \multirow[t]{2}{*}{ Blockholding directors } & & & & & -0.13814 & & & \\
\hline & & & & & $(0.149)$ & & & \\
\hline \multirow[t]{2}{*}{ Shareholder representatives } & & & & & -0.10157 & & & \\
\hline & & & & & $(0.095)$ & & & \\
\hline \multirow[t]{2}{*}{ Family representatives } & & & & & 0.40055 & $(* * *)$ & & \\
\hline & & & & & $(0.122)$ & & & \\
\hline \multirow[t]{2}{*}{ Full Independence } & & & & & & & -0.09892 & \\
\hline & & & & & & & $(0.076)$ & \\
\hline \multirow[t]{2}{*}{ Total outside activities } & 0.00641 & & -0.01630 & & 0.00390 & & -0.01518 & \\
\hline & $(0.012)$ & & $(0.011)$ & & $(0.012)$ & & $(0.011)$ & \\
\hline \multirow[t]{2}{*}{$\log$ Board size } & 0.13911 & $(* *)$ & 0.05103 & & 0.16366 & $(* *)$ & 0.04225 & \\
\hline & $(0.069)$ & & $(0.070)$ & & $(0.071)$ & & $(0.069)$ & \\
\hline \multirow[t]{2}{*}{ log Firm age } & -0.02942 & & -0.03186 & $(*)$ & -0.02180 & & -0.03136 & $(*)$ \\
\hline & $(0.019)$ & & $(0.019)$ & & $(0.019)$ & & $(0.019)$ & \\
\hline \multirow[t]{2}{*}{ Ownership concentration } & -0.16874 & $(*)$ & -0.13361 & & -0.17613 & $(*)$ & -0.17097 & $(*)$ \\
\hline & $(0.090)$ & & $(0.091)$ & & $(0.100)$ & & $(0.095)$ & \\
\hline \multirow[t]{2}{*}{ Sales Growth } & 0.18162 & $(*)$ & 0.19021 & $(*)$ & 0.18654 & $(*)$ & 0.19391 & $(*)$ \\
\hline & $(0.100)$ & & $(0.102)$ & & $(0.099)$ & & $(0.101)$ & \\
\hline Diversification & -0.15018 & $(* * *)$ & -0.19756 & $(* * *)$ & -0.15051 & $(* * *)$ & -0.19290 & $(* * *)$ \\
\hline
\end{tabular}




\begin{tabular}{|c|c|c|c|c|c|c|c|c|}
\hline \multirow{3}{*}{$\log$ Firm size } & $(0.045)$ & & $(0.045)$ & & $(0.045)$ & & $(0.046)$ & \multirow{3}{*}{$(* *)$} \\
\hline & 0.03132 & $(* *)$ & 0.02924 & $(* *)$ & 0.02147 & & 0.03157 & \\
\hline & $(0.014)$ & & $(0.014)$ & & $(0.014)$ & & $(0.014)$ & \\
\hline Industry & included & & included & & included & & included & \\
\hline Year & included & & included & & included & & included & \\
\hline Multiple $\mathrm{R}^{2}$ & 0.3476 & & 0.3211 & & 0.3571 & & 0.3212 & \\
\hline Adjusted $\mathrm{R}^{2}$ & 0.3400 & & 0.3144 & & 0.3483 & & 0.3145 & \\
\hline F-statistic & 24.3 & $* * *$ & 23.1 & $* * *$ & 22.5 & $* * *$ & 23.1 & $* * *$ \\
\hline
\end{tabular}

NOTE. - The table presents regression coefficient estimates for independence variables. The sample consists of 1,494 firm-year observations. Cluster-robust standard errors are reported in parentheses.

$* p<.10$.

$* * p<.05$.

$* * * p<.01$. 
Table 8

OUTSIDE ACTIVITIES

\begin{tabular}{|c|c|c|c|c|c|c|c|c|}
\hline \multirow{3}{*}{$\begin{array}{l}\text { Independent } \\
\text { Variables } \\
\text { (Intercept) }\end{array}$} & \multicolumn{7}{|c|}{ Dependent Variable: Tobin's Q } & \multirow{4}{*}{$(* * *)$} \\
\hline & \multicolumn{2}{|l|}{ (I) } & \multicolumn{2}{|l|}{ (II) } & \multicolumn{2}{|l|}{ (III) } & (IV) & \\
\hline & 1.66954 & $(* * *)$ & 1.50640 & $(* * *)$ & 1.62127 & $(* * *)$ & 1.49788 & \\
\hline & $(0.250)$ & & $(0.245)$ & & $(0.252)$ & & $(0.245)$ & \\
\hline \multirow[t]{2}{*}{ Outside CEO positions } & -0.13211 & & & & -0.17377 & $(*)$ & & \\
\hline & $(0.098)$ & & & & $(0.100)$ & & & \\
\hline \multirow[t]{2}{*}{ Outside officer positions } & -0.27637 & $(* * *)$ & & & -0.25438 & $(* * *)$ & & \\
\hline & $(0.084)$ & & & & $(0.085)$ & & & \\
\hline \multirow[t]{2}{*}{ Chairmanships } & & & 0.07220 & $(*)$ & 0.07122 & $(*)$ & & \\
\hline & & & $(0.040)$ & & $(0.042)$ & & & \\
\hline \multirow[t]{2}{*}{ Directorships } & & & -0.01104 & & -0.00894 & & & \\
\hline & & & $(0.019)$ & & $(0.020)$ & & & \\
\hline \multirow[t]{2}{*}{ Interest group members } & & & & & 0.01378 & & & \\
\hline & & & & & $(0.072)$ & & & \\
\hline \multirow{2}{*}{\multicolumn{2}{|c|}{ Politically affiliated members }} & & & & 0.00090 & & & \\
\hline & & & & & $(0.130)$ & & & \\
\hline \multirow[t]{2}{*}{ Charity members } & & & & & -0.01044 & & & \\
\hline & & & & & $(0.046)$ & & & \\
\hline \multirow[t]{2}{*}{ Advisory appointments } & & & & & 0.00012 & & & \\
\hline & & & & & $(0.073)$ & & & \\
\hline \multirow[t]{2}{*}{ Commission members } & & & & & -0.24031 & & & \\
\hline & & & & & $(0.151)$ & & & \\
\hline \multirow[t]{2}{*}{ SPI directorships } & & & & & & & -0.02503 & \\
\hline & & & & & & & $(0.057)$ & \\
\hline \multirow[t]{2}{*}{ Independence } & -0.50915 & $(* * *)$ & -0.51596 & $(* * *)$ & -0.51386 & $(* * *)$ & -0.49741 & $(* * *)$ \\
\hline & $(0.089)$ & & $(0.091)$ & & $(0.091)$ & & $(0.092)$ & \\
\hline \multirow[t]{2}{*}{$\log$ Board size } & 0.11641 & $(*)$ & 0.12508 & $(*)$ & 0.11039 & & 0.10873 & \\
\hline & $(0.069)$ & & $(0.070)$ & & $(0.074)$ & & $(0.071)$ & \\
\hline \multirow[t]{2}{*}{ log Firm age } & -0.01972 & & -0.02317 & & -0.01704 & & -0.02490 & \\
\hline & $(0.019)$ & & $(0.019)$ & & $(0.019)$ & & $(0.019)$ & \\
\hline \multirow[t]{2}{*}{ Ownership concentration } & -0.18786 & $(* *)$ & -0.18238 & $(* *)$ & -0.16573 & $(*)$ & -0.17582 & $(*)$ \\
\hline & $(0.089)$ & & $(0.090)$ & & $(0.096)$ & & $(0.090)$ & \\
\hline Sales Growth & 0.13568 & & 0.15534 & & 0.15408 & & 0.14475 & \\
\hline
\end{tabular}




\begin{tabular}{|c|c|c|c|c|c|c|c|c|}
\hline & $(0.100)$ & & $(0.101)$ & & $(0.101)$ & & $(0.100)$ & \\
\hline \multirow[t]{2}{*}{ Diversification } & -0.18005 & $(* * *)$ & -0.18410 & $(* * *)$ & -0.19320 & $(* * *)$ & -0.17891 & $(* * *)$ \\
\hline & $(0.045)$ & & $(0.045)$ & & $(0.046)$ & & $(0.045)$ & \\
\hline \multirow[t]{2}{*}{$\log$ Firm size } & 0.02169 & & 0.02674 & $(*)$ & 0.02433 & $(*)$ & 0.03068 & $(* *)$ \\
\hline & $(0.014)$ & & $(0.014)$ & & $(0.014)$ & & $(0.014)$ & \\
\hline Industry & included & & included & & included & & included & \\
\hline Year & included & & included & & included & & included & \\
\hline Multiple $\mathrm{R}^{2}$ & 0.3394 & & 0.3356 & & 0.3422 & & 0.3342 & \\
\hline Adjusted $\mathrm{R}^{2}$ & 0.3321 & & 0.3284 & & 0.3333 & & 0.3273 & \\
\hline F-statistic & 24.2 & $* * *$ & 23.8 & $* * *$ & 19.9 & $* * *$ & 24.5 & $* * *$ \\
\hline
\end{tabular}


Table 9

SuMmary StATISTICS OF MEETING VARIABLES

\begin{tabular}{|c|c|c|c|c|c|c|}
\hline \multirow[b]{2}{*}{ Variable } & \multirow[b]{2}{*}{ Mean } & \multirow[b]{2}{*}{ Median } & \multicolumn{4}{|c|}{ Correlation matrix } \\
\hline & & & $\begin{array}{l}\text { Full } \\
\text { independence }\end{array}$ & Executives & $\begin{array}{l}\text { Total outside } \\
\text { activities }\end{array}$ & $\begin{array}{l}\text { SPI } \\
\text { directorships }\end{array}$ \\
\hline Total number of all board meetings & 17.610 & 15.000 & & & & \\
\hline Total hours of all board meetings & 71.380 & 66.500 & & & & \\
\hline Full independence & 0.351 & 0.286 & 1 & & & \\
\hline Executives & 0.114 & 0.000 & $-0.34 * * *$ & 1 & & \\
\hline Total outside activities & 3.366 & 3.143 & $0.17 *$ & $-0.27 * * *$ & 1 & \\
\hline SPI directorships & 0.387 & 0.333 & $0.22 * *$ & $-0.27 * * *$ & $0.15^{*}$ & 1 \\
\hline Number of board committees & 2.025 & 2.000 & & & & \\
\hline $\begin{array}{l}\text { NOTE. - The basis sample consist } \\
\text { and maximum (Max) for each variab } \\
* p<.10 \text {. } \\
* * p<.05 \text {. } \\
* * * p<.01 \text {. }\end{array}$ & of 155 & ad 94) & servations. 7 & ne table pre & & minimum (Min) \\
\hline
\end{tabular}


Table 10

\section{BoARd MeEtings}

\begin{tabular}{|c|c|c|c|c|}
\hline Independent & \multicolumn{3}{|c|}{ Dependent Variable } & \\
\hline \multirow[t]{4}{*}{ Variables } & Total number & & Total hours & \\
\hline & of all board & & of all board & \\
\hline & meetings & & meetings & \\
\hline & (I) & & (II) & \\
\hline \multirow[t]{2}{*}{ (Intercept) } & 2.24955 & $(* * *)$ & 3.79028 & $(* * *)$ \\
\hline & $(0.171)$ & & $(0.169)$ & \\
\hline \multirow[t]{2}{*}{ Full independence } & 0.04341 & & 0.05928 & \\
\hline & $(0.142)$ & & $(0.167)$ & \\
\hline \multirow[t]{2}{*}{ Executives } & -1.14487 & $(* * *)$ & -0.95881 & $(* *)$ \\
\hline & $(0.284)$ & & $(0.440)$ & \\
\hline \multirow[t]{2}{*}{ Total outside activities } & 0.05096 & $(* * *)$ & -0.02261 & \\
\hline & $(0.019)$ & & $(0.028)$ & \\
\hline \multirow[t]{2}{*}{ SPI directorship } & -0.23390 & $(* *)$ & 0.14082 & \\
\hline & $(0.100)$ & & $(0.112)$ & \\
\hline \multirow[t]{2}{*}{ Number of board committees } & 0.24556 & $(* * *)$ & 0.22728 & $(* * *)$ \\
\hline & $(0.044)$ & & $(0.047)$ & \\
\hline McFadden $R^{2}$ & 0.18546 & & 0.18835 & \\
\hline AIC & 1094.8 & & 1586.2 & \\
\hline Observations & 155 & & 94 & \\
\hline \multicolumn{5}{|c|}{ 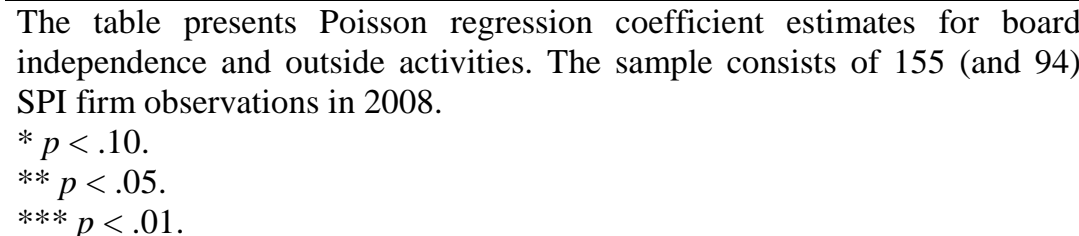 } \\
\hline
\end{tabular}

